Available online at GSC Online Press Directory

GSC Biological and Pharmaceutical Sciences

e-ISSN: 2581-3250, CODEN (USA): GBPSC2

Journal homepage: https://www.gsconlinepress.com/journals/gscbps

(RESEARCH ARTICLE)

\title{
Assessment of some herbicides for the control of purple nutsedge (Cyperus rotundus) in soybean (Glycine max (L.) Merrill)
}

\author{
Agahiu AE *
}

\begin{abstract}
Department of Crop Production, Faculty of Agriculture, Kogi State University, Anyigba, Nigeria.
\end{abstract}
Publication history: Received on 17 June 2020; revised on 21 July 2020; accepted on 24 July 2020

Article DOI: https://doi.org/10.30574/gscbps.2020.12.1.0191

\begin{abstract}
Field experiment was conducted at the Teaching and Research Farm, Faculty of Agriculture, Kogi State University, Anyigba in 2014 to assess the effects of some herbicides on the control of purple nutsedge in soybean. The field used for the trial was left fallow for about five years and predominantly infested with purple nutsedge. It was then ploughed, harrowed and ridged. The treatments applied consisted oflinuron [N-(3, 4-dichlorophenyl)-N-methoxy-N-methyl urea] at 2.0 and $2.5 \mathrm{~kg}$ a.i/ha; 2,4-D [ (2,4-dichlorophenoxy) acetic acid ] at 2.0 and $3.0 \mathrm{~kg}$ a.i/ha; glyphosate [N(phosphonomethyl) glycine] at 2.0 and $2.5 \mathrm{~kg}$ a.i/ha; a tank mixture of glufosinate [2-amino-4(hydroxymethylphosphinyl) butanoic acid] + fluazifop [ (R) -2-[5-(trifluoromethyl)-2- pyridinyl ] oxy] phenoxy] propanoic acid] at 2.5 and $3.0 \mathrm{~kg}$ a.i/ha, manual hoe weeding at 3,6 and 9 WAS and the weedy check. In this trial,the application of 2.0 and $2.5 \mathrm{~kg}$ a.i/ha of glyphosate was found to be most efficacious in the control of purple nutsedge. Glyphosate applied at both rates compared favourably with hoe weeding at 3,6 and 9 WAS in the control of purple nutsedge and resulted in the highest grain yield of soybean in the area. A tank mixture of glufosinate + fluazifop at 3.0 $\mathrm{kg}$ a;/ha equally gave a good control of purple nutsedge and the soybean grain yield produced therein was comparable to that obtained from plots treated with both rates of glyphosate or that were hoe weeded. Results obtained in this study suggest that glyphosate applied at $2.5 \mathrm{~kg}$ a.i/ha could provide alternative management option for the control of purple nutsedge to manual hoe-weeding and for ensuring higher grain yield of soybean.
\end{abstract}

Keywords: Herbicide; Weed biomass; Suppressed; Purple nutsedge; Control

\section{Introduction}

Soybean (Glycine max (L.) Merrill) an erect, much branched pubescent annual belongs to the family leguminosae sub family papilionoidae and the genus Glycine L. Nigeria is the largest soybean producer for food in West and Central Africa [1]. Its production is considerably hampered by intense weed infestation among which is purple nutsedge. Purple nutsedge ranks among the world's worst weeds. It is a perennial weed and propagate vegetatively from rhizomes, nutlets and /or seeds and resist many control practices commonly used in modern agriculture [2]. All crops are affected by weeds to some extent. The seriousness of infestation depends on the species and the prevailing circumstance. Average crop losses due to weed infestation are estimated at $25 \%$ but may be as high as $50 \%$ or even $80-100 \%$ with certain food crops [3]. Purple nutsedge (Cyperus rotundus) is a glumifloral monocotyledon belonging to the family, Cyperaceae. It causes severe depression in soybean grain yield if left uncontrolled in the crop life cycle especially during the early growth stage [4]. Green KA (2011) reported soybean grain yield loss of up to $80 \%$ by purple nutsedge infestation. Studies have shown the difficulty associated with the use of chemical to control purple nutsedge owing to its resistance to a number of herbicides. As revealed by Watson and Kent (2005), alachlor reduced the growth of purple nutsedge but achieved only marginal control. Purple nutsedge, where it predominates has caused 65-72\% grain loss in soybean [7]. Earlier work carried out indicated that alachlor and metolachlor delayed sprouting of tubers and killed shoots of yellow nutsedge and revealed that their control on the weed (purple nutsedge) was temporary [8; 9; 10; 11;

\footnotetext{
${ }^{*}$ Corresponding author: Agahiu AE
}

Copyright (C) 2020 Author(s) retain the copyright of this article. This article is published under the terms of the Creative Commons Attribution Liscense 4.0. 
12; 13]. Akinyemiju OA (1992) found out that chemical weed control is unsatisfactory in Nigeria owing to the narrow spectrum of weeds controlled and the short persistence of existing herbicides and the problem of escaped weeds through seed dormancy $[15 ; 16]$. Studies also indicated a serious yield reduction in cowpea grain infested heavily with milk weed to which $2.5 \mathrm{~kg}$ ai/ha of metolachlor was applied [17]. Weed control on maize farm was only effective for four (4) weeks after planting (WAP) through the application of $3.0 \mathrm{~kg} / \mathrm{ha}$ of primextra [14]. To achieve a much better weed control for optimum crop production, it is imperative that more persistent and effective herbicide be used so as to forestall re-infestation after the initial control application. The outcry of soybean farmers on account of the menace of infestation of purple nutsedge is in fact, very worrisome. Therefore, the objective of this trial was to assess the effects of some herbicides for the control of noxious purple nutsedge in soybean.

\section{Materials and methods}

The experiment carried at the Teaching and Research Farm, Faculty of Agriculture, Kogi State University, Anyigba was to assess the efficacy or otherwise of some selected herbicides for the control of purple nutsedge in soybean farm. The experimental field had been under purple nutsedge fallow for about five (5) years. The land used for the experiment was ploughed, harrowed and ridged. The plot size was $4 \mathrm{~m} \times 4 \mathrm{~m}$ while the net plot from where soybean was harvested was $3 \mathrm{~m} \mathrm{x} 3 \mathrm{~m}$. The blocks (replicates) were separated by $1.0 \mathrm{~m}$ while the plots were separated by $0.5 \mathrm{~m}$ from each other. The experimental design was a randomized complete block replicated three times. The treatments consisted of linuron at 2.0 and $2.5 \mathrm{~kg}$ a.i $/ \mathrm{ha} ; 2,4-\mathrm{D}$ at 2.0 and $3.0 \mathrm{~kg}$ a.i $/ \mathrm{ha}$; glyphosate at 2.0 and $2.5 \mathrm{~kg}$ a.i/ha; glufosinate + fluazifop at 2.5 and $3.0 \mathrm{~kg}$ a.i/ha; hoe weeding at 3,6 and 9 WAS and a weedy check. In this trial, weeds other than purple nutsedge were constantly removed manually in all the treatment plots. A blue knapsack sprayer calibrated to deliver $250 \mathrm{l} / \mathrm{ha}$ of spray solution was used in the application of herbicides. The soybean variety used in this experiment was TGX 1455-2E. Five soybean plants were tagged in each plot for the purpose of data collection. Data were collected on the following parameters; weed control rating, weed density, weed biomass, plant height, number of pods/plant, number of seeds/plant and the total grain yield. Visual weed control rating was determined on a scale of $0-10$, where $0-4.0$ indicates poor weed control; 4.1-7.9 indicates satisfactory weed control while 8-10 represents excellent weed control. Analysis of Variance (ANOVA) procedure was used for statistical analysis of the data collected and the mean comparison was carried out using Duncan's Multiple Range Test (DMRT).

\section{Results}

The test conducted on the Physico-chemical properties of the experimental site indicated that texturally, the soil was a sandy loam suggesting that it was suitable for soybean production (Table 1). Purple nutsedge constituted about $90 \%$ of the total weed flora of the experimental field. The few other species found on the field were Sclerocarpus africanus, Croton lobatus, Mariscus alternifolius, Brachari adeflexa and Chloris pilosa. As indicated in Table 2, only glyphosate at both rates gave excellent control of purple nutsedge among the herbicide treated plots and which was comparable to the hoe weeded plots at 3,6, and 9 WAS. Glufosinate + fluazifop and 2,4-D at $3.0 \mathrm{~kg}$ a.i/ha each gave satisfactory purple nutsedge control. The weed control score at 8 WAS in plots treated with 2.0 and $2.5 \mathrm{~kg}$ a.i/ha of glyphosate and $3.0 \mathrm{~kg}$ a.i/ha each of 2,4-D and glufosinate + fluazifop was much higher in comparison with the other treatments except the hoe weeded plots. This indicated a better weed control option. Weed densities in plots treated with 2.0 and $3.0 \mathrm{~kg}$ a.i/ha of glyphosate and that of the hoe weeded plots were significantly different from the other treatments. Among the treatments, the weedy check recorded significantly the highest weed density $\left(188.2 / \mathrm{m}^{2}\right)$. Weed biomass was most minimal with the application of 2.0 and $2.5 \mathrm{~kg}$ a.i $/$ ha of glyphosate with the least been recorded on plots that were hoe weeded. Weed biomass in the weedy check was enormous. The weedy check treatment was significantly different from the other weed control treatments in plant height. The plant height in the weedy check was $31 \mathrm{~cm}$ indicating that soybean plants were significantly shorter in comparison to plants subjected to other treatments (Table 3). The highest soybean grain yield $(1126 \mathrm{~kg} / \mathrm{ha})$ was obtained from the hoe weeded plots which was statistically similar to yields in plots to which 2.0 and $2.5 \mathrm{~kg}$ a.i/ha of glyphosate was applied. In the same vein, number of pods/plant and number of seeds/plant in these treatments (hoe weeding and application of 2.0 and $2.5 \mathrm{~kg}$ a.i/ha of glyphosate) followed a similar trend. Number of pods/plant, number of seeds/plant and grain yield in plots that received $3.0 \mathrm{~kg}$ a.i/ha of glufosinate + fluazifop were significantly different from results obtained in plots treated with 2.0 and $2.5 \mathrm{~kg}$ a.i/ha of linuron and 2.0 and $3.0 \mathrm{~kg}$ a.i/ha of 2,4-D in these parameters. The weedy check recorded the least in all the parameters evaluated except the weed density and weed biomass. 
Table 1 Physical and chemical properties of the soil $(0-20 \mathrm{~cm})$ at the experimental site.

\begin{tabular}{ll}
\hline Soil property & Value \\
\hline $\mathrm{Ca}(\mathrm{ppm})$ & 358.80 \\
$\mathrm{Na}(\mathrm{ppm})$ & 9.97 \\
$\mathrm{Mg}(\mathrm{ppm})$ & 69.85 \\
$\mathrm{Mn}(\mathrm{ppm})$ & 55.0 \\
$\mathrm{Zn}(\mathrm{ppm})$ & 1.11 \\
Fe (ppm) & 128.72 \\
Cu (ppm) & 1.24 \\
pH(H20) & 5.70 \\
Coarse sand (\%) & 16.60 \\
Fine sand (\%) & 37.45 \\
Silt $(\%)$ & 36.72 \\
Clay (\%) & 6.0 \\
Available P (ppm) & 5.50 \\
Exchangeable K (ppm) & 44.80 \\
Total N (\%) & 0.04 \\
Organic carbon (\%) & 0.70 \\
\hline
\end{tabular}

Table 2 Effect of weed control treatments on purple nutsedge in Anyigba

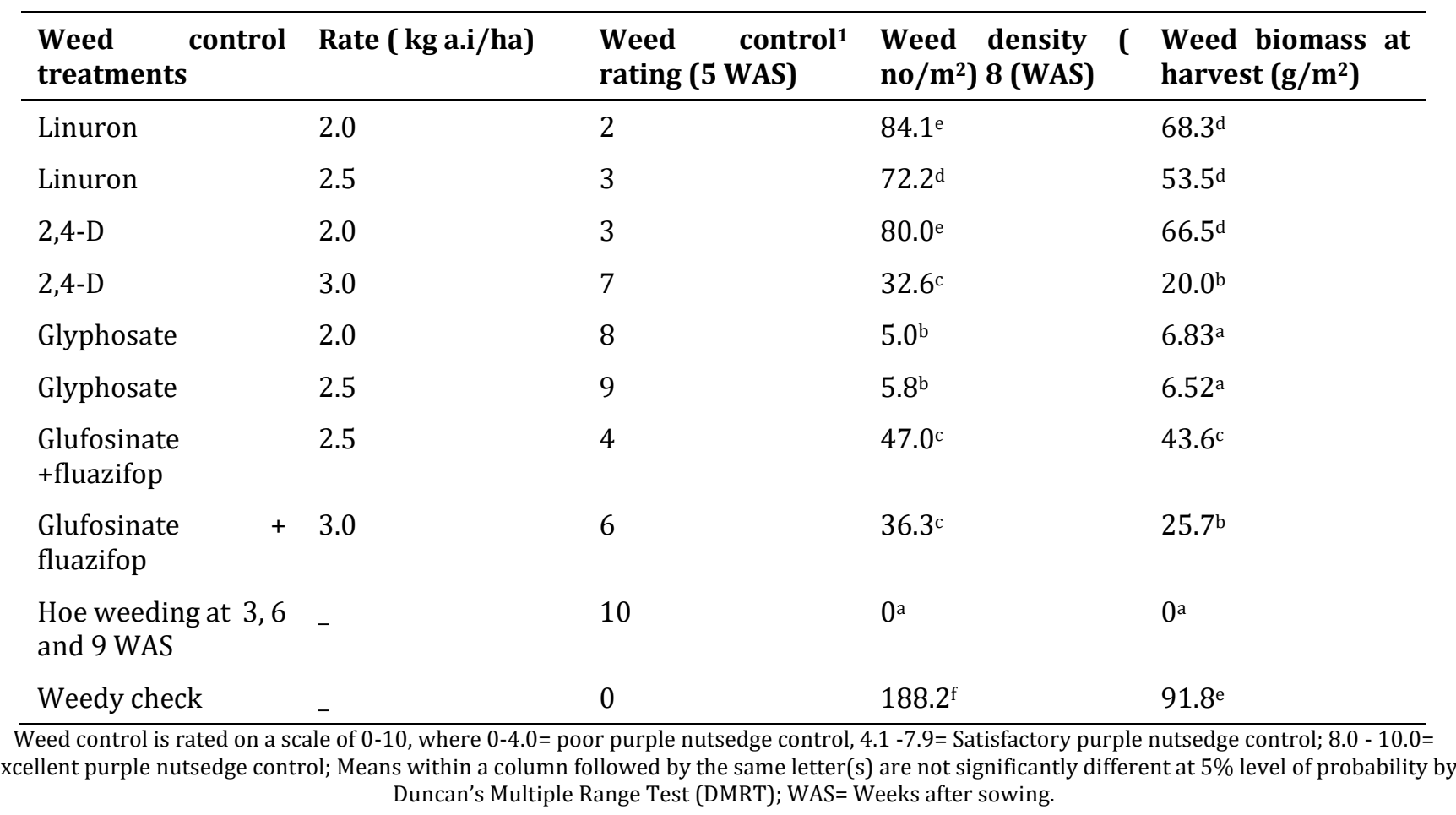


Table 3 Effect of weed control treatments on plant height, number of pods /plant, number of seeds/plant and grain yield of soybean in Anyigba.

\begin{tabular}{|c|c|c|c|c|c|c|c|}
\hline $\begin{array}{l}\text { Weed control } \\
\text { treatments }\end{array}$ & $\begin{array}{l}\text { Rate (kg } \\
\text { a.i/ha) }\end{array}$ & Plant height (cm) & $\begin{array}{l}\text { Number } \\
\text { pods/plant }\end{array}$ & of & $\begin{array}{l}\text { Number } \\
\text { seeds/plant }\end{array}$ & of & $\begin{array}{l}\text { Grain yield } \\
\text { (kg/ha) }\end{array}$ \\
\hline Linuron & 2.0 & $45^{b}$ & $21^{c}$ & & $34^{\mathrm{d}}$ & & $370^{\mathrm{d}}$ \\
\hline Linuron & 2.5 & $43^{b}$ & $25^{c}$ & & $38^{\mathrm{d}}$ & & $381^{\mathrm{d}}$ \\
\hline 2,4-D & 2.0 & $40^{\mathrm{b}}$ & $21^{c}$ & & $36^{d}$ & & $379^{d}$ \\
\hline 2,4-D & 3.0 & $42^{\mathrm{b}}$ & $25^{\mathrm{c}}$ & & $31^{\mathrm{d}}$ & & $334 \mathrm{e}$ \\
\hline Glyphosate & 2.0 & $40^{\mathrm{b}}$ & $44^{\mathrm{b}}$ & & $80^{\mathrm{b}}$ & & $1093^{b}$ \\
\hline 85Glyphosate & 2.5 & $44^{\mathrm{b}}$ & $45^{b}$ & & $85^{b}$ & & $1108^{b}$ \\
\hline $\begin{array}{l}\text { Glufosinate } \\
\text { +fluazifop }\end{array}$ & 2.5 & $45^{b}$ & $36^{\mathrm{b}}$ & & $45^{c}$ & & $482^{c}$ \\
\hline $\begin{array}{l}\text { Glufosinate } \\
\text { +fluazifop }\end{array}$ & 3.0 & $43^{b}$ & $40^{\mathrm{b}}$ & & $70^{\mathrm{b}}$ & & $1029^{b}$ \\
\hline $\begin{array}{l}\text { Hoe weeding at } \\
3,6 \text { and } 9 \text { WAS }\end{array}$ & - & $44^{\mathrm{b}}$ & $47^{b}$ & & $88^{\mathrm{b}}$ & & $1126^{b}$ \\
\hline Weedy check & _- & $31^{\mathrm{a}}$ & $13^{\mathrm{a}}$ & & $9^{a}$ & & $64^{\mathrm{a}}$ \\
\hline
\end{tabular}

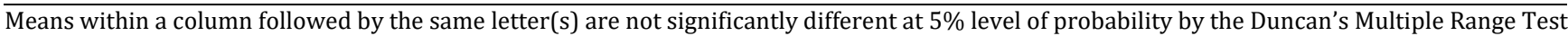
(DMRT); WAS= Weeks after sowing

\section{Discussion}

As shown in the Table 1, excellent control of purple nutsedge was achieved in plots treated with 2.0 and $2.5 \mathrm{~kg}$ ai/ha of glyphosate. And this was comparable to the hoe weeded plots that recorded the highest weed control rating. Satisfactory purple nutsedge control was also obtained in plots that received 2.5 and $3.0 \mathrm{~kg}$ a.i/ha of glufosinate +fluazifop and 3.0 a.i/ha of 2,4-D. This showed that these treatments controlled purple nutsedge more effectively than the application of 2.0 and $2.5 \mathrm{~kg}$ a.i/ha of linuron. This is in agreement with the findings that purple nutsedge was severely suppressed by the application of $1.75 \mathrm{~kg}$ a.i $/$ ha of glyphosate [18]. The control of purple nutsedge using 2.0 and $2.5 \mathrm{~kg}$ a.i/ha of linuron and $2.0 \mathrm{~kg}$ a.i/ha of 2,4-D was poor indicating the ineffectiveness of these herbicides at the rates specified. Weed control rating of the herbicides at these rates was similar to the results obtained on the weedy check plots. This affirms earlier observation that the use of $3.0 \mathrm{~kg}$ a.i/ha of linuron did not control purple nutsedge effectively [19]. As revealed in this study, even the lower rates of 2.0 and $2.5 \mathrm{~kg}$ a.i $/ \mathrm{ha}$ of glyphosate provided a better control of purple nutsedge than glufosinate + fluazifop at $3.0 \mathrm{~kg}$ a.i/ha and proved the best option for the control of the weed besides manual hoe weeding. Though, the application of $3.0 \mathrm{~kg}$ a.i/ha of 2,4-D satisfactorily suppressed the growth of purple nutsedge, the rate appears to be phototoxic to the crop as some plants subjected to the herbicides at this rate were chlorotic leading to depressed pod and grain yields. This corroborates the report thatchlorosiswas observed on soybean plants on the application of $2.8 \mathrm{~kg}$ a.i/ha of cinosulfuron and 2,4-D for the control of yellow nutsedge[20].

\section{Conclusion}

In this trial, it has been found out that hoe weeding controlled purple nutsedge most effectively. Considering the fact that we are in the era where emphasis is placed on large scale production of crop to ensure abundant food for the teeming world population and to feed ever expanding industries, the author advocates for the use of chemical especially glyphosate in the control of purple nutsedge. Glyphosate applied at $2.5 \mathrm{~kg}$ a.i $/$ ha controls purple nutsedge as effectively as hoe weeding which in fact, translates into optimum growth performance and a robust grain yield of soybean in the region. 


\section{Compliance with ethical standards}

\section{Acknowledgments}

The author wishes to thank the University management for allowing me the use of part of the institution land for carrying out the field experiment. The contributions of the technical staff of the Department of crop production of the University are very much appreciated.

\section{Disclosure of conflict of interest}

There is no conflict of interest in this study.

\section{References}

[1] Root CB Musa FS and Talabi MB. (2007). Competition and growth forms in soybean in the Savanna Journal of Ecology, 61, 48-61.

[2] Ahom RI. (1996). Response of varieties of soybean (Glycine max (L.) Merril) and weeds to metobromuron + metolachlor. An unpublished M.Sc. dissertation, Department of Crop Science, University of Nigeria, Nsukka, 39.

[3] Ivans GW Moody K and Egunjobi JK. (1998). West African Weeds. Oxford University Press, Nigeria, 255.

[4] Afolayan TS. (1995). Improved culture and management of legume crops. Proc. Pre-season in-service Training Workshop for Agricultural Development Project of Benue State. University of Agriculture, Makurdi, 54- 62.

[5] Green KA. (2011). Ficus exasperata control with bentazon in soybean. Proceedings of North Weed Science Society, 24, 128-140.

[6] Watson J0 and Kent PC. (2005). Adjuvant for increasing purple nutsedge control in maize (Zea mays). Weed Science, 15, 115-122.

[7] Jerry VS and Nwankwo KS. (2013). Control of weeds in soybean (Glycine max (L) with primextra, alachlor and metolachlor. Weed Science, 14, 216-228.

[8] Bell RS Lachman WH Rahm EM and Sweet RD. (1962). Life history studies as related to weed control in the Northeast. 1. Nutgrass. R.1. Agricultural Experiment Station Bulletin. No, 364.

[9] Keeley PE Carter CH and Miller JH. (1972). Evaluation of the relative phototoxicity of herbicides to cotton and nutsedge. Weed Science, 20, 71-74.

[10] Armstrong TF Moggitt WF and Penner D. (1973). Yellow nutsedge control with alachlor. Weed Science, 21, $354-$ 357.

[11] Dixon GA Stoller EW and McGlammery MD. (1980). Acetanilide herbicides for purple nutsedge control in corn. Weed Science, 28, 593-598.

[12] Dixon GA and Stoller EW. (1982). Differential toxicity, absorption, translocation and metabolism of metolachlor in corn and purple nutsedge. Weed Science, 30, 225-230.

[13] Ray BR and Wilcox M. (1969). Chemical fallow control of nutsedge. Weed Res, 9, 86-94.

[14] Akinyemiju OA. (1992). Weed control in maize with acetochlor alone and in combination with atrazine. Nigeria Journal of Weed Science, 5, 53-62.

[15] Melifonwu AA. (1992). Control of Mimosa invisa in maize (Zea mays) with atrazine and its mixtures with alachlor and metolachlor. Nigeria Journal of Weed Science, 7, 9-14.

[16] Avav T Magani IE and Ahom RI. (2010). Herbicides resistant weeds. Aboki publishers, 43 New Bridge (Otukpo) road, Makurdi, Benue State, Nigeria, 71.

[17] Akobundu IO. (1982). Weed control Vignaunguiculata in the humid tropics. Weed Science, 30, 331- 334.

[18] Sharma TP. (2005). Effect of chemical weed control on crop and weed biomass,weed competition index in soybean ecosystems. Indian Journal Agricultural Sciences, 41(3), 162-181.

[19] Steward OB. (2000). Control of purple nutsedge with glyphosate, linuron and fluazifop-butyl in soybean (Glycine max L.) production in the savanna zone of Nigeria. Plants Today (August to October, 1988), 150-161. 
Agahiu AE / GSC Biological and Pharmaceutical Sciences, 2020, 12(01), 229-234

[20] Ishaya ST. (2010). Efficacy of different herbicides for controlling weeds in tomato. Weed Science Society of Pakistan, 20(3), 200 - 220.

\section{How to cite this article}

Agahiu AE. (2020). Assessment of some herbicides for the control of purple nutsedge (Cyperus rotundus) in soybean (Glycine max (L.) Merrill). GSC Biological and Pharmaceutical Sciences, 12(1), 229-234. 